\title{
Fluoroquinolone susceptibilities to methicillin-resistant and susceptible coagulase-negative Staphylococcus isolated from eye infection
}

\author{
Suscetibilidadedos Staphylococcus coagulasenegativometicilina-resistentes \\ e suscetíveis isolados em infecções oculares
}

\author{
Adália Dias Dourado Oliveira ${ }^{1}$ \\ Ana Luisa Höfling-Lima² \\ Rubens Belfort Jr. ${ }^{3}$ \\ Maria de Fátima Gayoso ${ }^{4}$ \\ Waldemar Francisco ${ }^{5}$
}

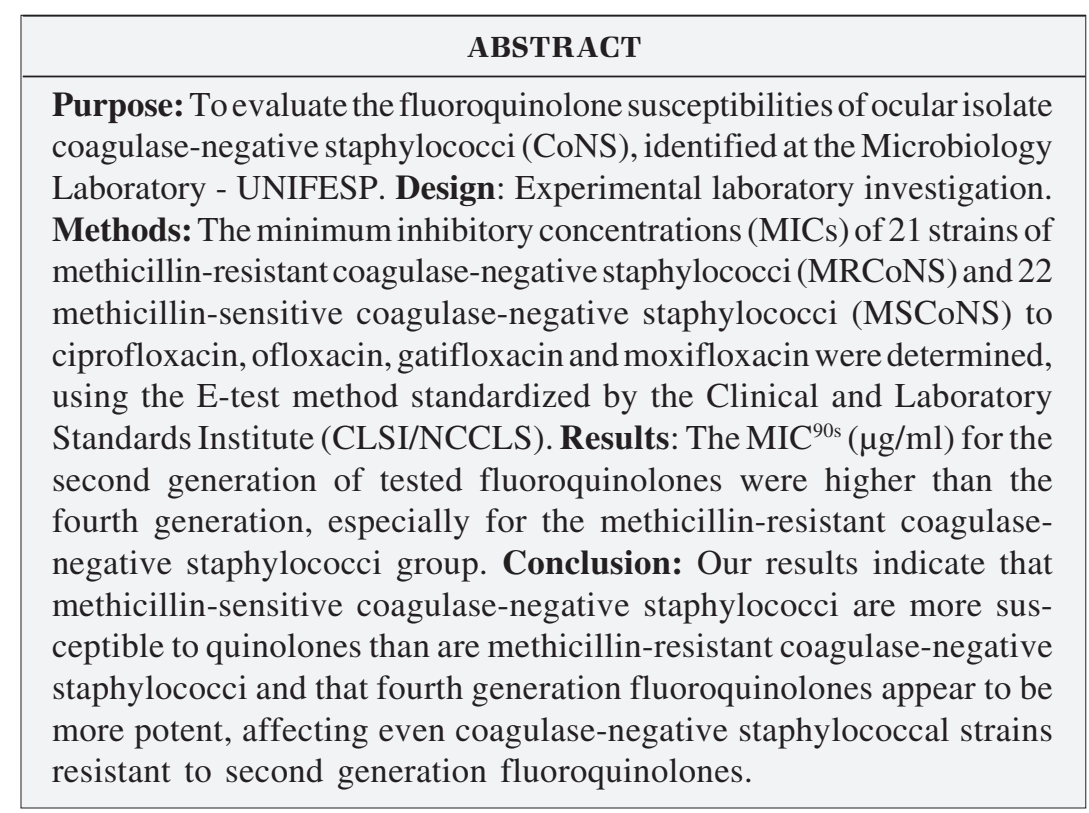

Keywords: Drug resistance, microbial; Eye infections, bacterial/microbiology; Staphylococcus/isolation \& purification; Coagulase; Fluoroquinolones; Methicillin-resistance

\section{INTRODUCTION}

Coagulase-negative staphylococci are commonly isolated bacteria mixed with the more typical ocular flora, and can lead to major infections, including keratitis, conjunctivitis and endophthalmitis. These infections represent serious ocular conditions with significant sight-threatening consequences, particularly if aggressive, appropriate therapy is not instituted in a timely manner ${ }^{(1-4)}$.

In recent years, many new antibiotics and synthetic antimicrobial eye drops have been developed and used in the treatment of ocular infections. Any one of these, however, may alter drug sensitivity of bacteria on the ocular surface. There are many reports in the ophthalmic literature concerning infections due to methicillin-resistant coagulase-negative staphylococci ${ }^{(5-7)}$.

The quinolones are one class of antibiotics that has been used to treat these infections, since their introduction into the ophthalmic community in $1991^{(8-9)}$.

Ciprofloxacin and ofloxacin have soon achieved great acceptance in the treatment of ocular infections. These antibiotics (ciprofloxacin, ofloxacin, 
moxifloxacin and gatifloxacin) provide: broad-spectrum coverage against most aerobic gram-negative and gram-positive bacteria, low toxicity, safety, good ocular surface penetration, prolonged tear film concentration, stability at room temperature, and good availability ${ }^{(5,10)}$. Unfortunately, recent reports of bacterial resistance to these second generation fluoroquinolones have had an impact on their acceptance, with a decrease in their use and the introduction of the fourth generation fluoroquinolones as an alternative to increase the spectrum of action, mostly against gram-positive $\operatorname{cocci}^{(5,10-14)}$.

Microbial resistance to fluoroquinolones is the result of genetic changes in one or more of four major bacterial mechanisms: enzymes for DNA synthesis; gyrase protecting proteins; cell permeability or drug efflux ${ }^{(15)}$.

The 8-methoxyfluoroquinolones, gatifloxacin and moxifloxacin, have enhanced activity against gram-positive pathogens, thereby increasing the probability that strains resistant to the older fluoroquinolones will be susceptible. These newer fluoroquinolones are less prone to encourage the development of resistance on a number of fronts, primarily because of their higher activity against gram-positive pathogens, but for other reasons as well, such as the necessity of two mutations: one in the topoisomerase IV and a second in the DNA gyrase gene ${ }^{(12)}$.

The purpose of this study was to evaluate and compare the antibiotic susceptibility results of CoNS isolated from eye infections at the Microbiology Laboratory of the Vision of Institute, Federal University of São Paulo, Brazil.

\section{METHODS}

Forty-three CoNS ocular isolates were studied and divided into two groups according to resistance to methicillin; these consisted of 21 methicillin-resistant organisms (3 endophthalmitis, 10 keratitis and 8 conjunctivitis) and 22 methicillin-sensitive organisms (11 endophthalmitis, 9 keratitis and 2 conjunctivitis).

Methicillin-resistance of the strains was determined by the Kirby-Bauer disk diffusion method using $1 \mu \mathrm{g}$ oxacillin disk (Cecon, São Paulo, Brazil) according to the criteria of the Clinical and Laboratory Standards Institute (CLSI/NCCLS $)^{(16)}$.

Antibiotic susceptibility of each bacterial isolate to ciprofloxacin, ofloxacin, gatifloxacin and moxifloxacin was determined by two methods: Kirby-Bauer disk diffusion (Cecon, São Paulo, Brazil) and E-test (AB Biodisk, Solna, Sweden) ${ }^{(14)}$. Interpretation for susceptible and non-susceptible (intermediate and resistant) responses were in accordance with the criteria of the Clinical and Laboratory Standards Institute (CLSI/ NCCLS) document M100-S15, Vol. $25 \mathrm{~N}^{\circ} 1 \mathrm{NCCLS}$ : ciprofloxacin $\mathrm{S}=<1 \mu \mathrm{g} / \mathrm{ml}, \mathrm{R}=>4 \mu \mathrm{g} / \mathrm{ml}$; ofloxacin $\mathrm{S}=<1 \mu \mathrm{g} / \mathrm{ml}, \mathrm{R}=>4 \mu \mathrm{g} / \mathrm{ml}$; gatifloxacin $\mathrm{S}=<0,5 \mu \mathrm{g} / \mathrm{ml}, \mathrm{R}=>2 \mu \mathrm{g} / \mathrm{ml}$; moxifloxacin $\mathrm{S}=$ $<0,5 \mu \mathrm{g} / \mathrm{ml}, \mathrm{R}=>2 \mu \mathrm{g} / \mathrm{ml}^{(16)}$.

Minimal inhibitory concentration 90 s $\left(\mathrm{MIC}^{90}\right)$ were determinated for each group, methicillin-resistant and methicillinsensitive coagulase-negative staphylococci.

The results were statistically evaluated by the MannWhitney and the Friedman tests.

\section{RESULTS}

Table 1 summarizes the $\mathrm{MIC}^{90}$ of the 21 methicillin-resistant isolates and table 2 summarizes the $\mathrm{MIC}^{90} \mathrm{~s}$ of the 22 methicillin-sensitive isolates to ciprofloxacin, ofloxacin, gatifloxacin, and moxifloxacin.

For all tested antibiotics, MIC values were statistically higher for the methicillin-resistant group than for the methicillin-sensitive group $(\mathrm{p}<0.05)$ (Table 3$)$.

Comparing the MIC values for the four antibiotics by the Friedman test, those for ofloxacin were statistically significantly higher in both groups: ofloxacin > ciprofloxacin > (gatifloxacin=moxifloxacin $)(p<0.001)($ Table 3$)$.

There was no statistically significantly difference between both groups comparing the resistance of the four antibiotics by the two methods (Tables 4 and 5).

\begin{tabular}{|c|c|c|c|c|}
\hline & $\begin{array}{c}\text { Range } \\
(\mu \mathrm{g} / \mathrm{ml})\end{array}$ & $\begin{array}{c}\mathrm{MIC}^{90} \\
(\mu \mathrm{g} / \mathrm{ml})\end{array}$ & $\begin{array}{c}\% \text { Sensitivity } \\
\text { disc }\end{array}$ & $\begin{array}{c}\% \text { Sensitivity } \\
\text { E-test }\end{array}$ \\
\hline Cipro & $0.047-32$ & 32 & $52.4 \%$ & $28.60 \%$ \\
\hline Oflox & $0.094-32$ & 32 & $57.1 \%$ & $23.80 \%$ \\
\hline Gati & $0.032-2.0$ & 2.0 & $71.4 \%$ & $38.10 \%$ \\
\hline Moxi & $0.023-3.0$ & 3.0 & $81.0 \%$ & $33.33 \%$ \\
\hline
\end{tabular}

Table 2. Susceptibilities of methicillin-sensitive coagulase-negative Staphylococcus isolates to fluoroquinolones

\begin{tabular}{|lllcc|} 
& \multicolumn{1}{c}{$\begin{array}{c}\text { Range } \\
(\mu \mathrm{g} / \mathrm{ml})\end{array}$} & $\begin{array}{c}\mathbf{M I C}^{90} \\
(\mu \mathrm{g} / \mathrm{ml})\end{array}$ & $\begin{array}{c}\text { \% Sensitivity } \\
\text { disc }\end{array}$ & $\begin{array}{c}\text { \% Sensitivity } \\
\text { E-test }\end{array}$ \\
Cipro & $0.064-0.25$ & 0.25 & $95.5 \%$ & $95.5 \%$ \\
Oflox & $0.190-1.0$ & 1.0 & $95.5 \%$ & $90.9 \%$ \\
Gati & $0.047-0.125$ & 0.125 & $100.0 \%$ & $95.5 \%$ \\
Moxi & $0.032-0.125$ & 0.125 & $95.5 \%$ & $95.5 \%$ \\
MIC=minimum inhibitory concentrations; Cipro=ciprofloxacin; Oflox=ofloxacin; \\
Gati= gatifloxacin; Moxi= moxifloxacin
\end{tabular}

\begin{tabular}{|c|c|c|c|}
\hline Antibiotics & $\begin{array}{l}\text { MR CoNS } \\
(n=21)\end{array}$ & $\begin{array}{l}\text { MS CoNS } \\
(n=22)\end{array}$ & $\begin{array}{c}\text { Mann-Whitney } \\
\text { test }\end{array}$ \\
\hline Ciprofloxacin & $\begin{array}{c}0.820-7.000 \\
3.00\end{array}$ & $\begin{array}{c}0.125-0.190 \\
0.158\end{array}$ & $\mathrm{p}<0.001$ \\
\hline Ofloxacin & $\begin{array}{c}1.190-32.000 \\
8.00\end{array}$ & $\begin{array}{c}0.250-0.500 \\
0.380\end{array}$ & $p=0.001$ \\
\hline Gatifloxacin & $\begin{array}{c}0.188-2.000 \\
1.50\end{array}$ & $\begin{array}{c}0.064-0.102 \\
0.094\end{array}$ & $p<0.001$ \\
\hline Moxifloxacin & $\begin{array}{c}0.380-1.750 \\
1.00\end{array}$ & $\begin{array}{c}0.064-0.094 \\
0.094\end{array}$ & $p<0.001$ \\
\hline
\end{tabular}




\begin{tabular}{|c|c|c|c|c|c|c|}
\hline Groups & Result & Cipro & Oflox & Gati & Moxi & Friedman test \\
\hline \multirow{2}{*}{$\begin{array}{l}\text { MR CoNS } \\
(n=21)\end{array}$} & Not susceptible & $10(47.6 \%)$ & 9 (42.9\%) & $6(28.6 \%)$ & $4(19.0 \%)$ & \multirow{2}{*}{$p=0.096$} \\
\hline & Susceptible & $11(52.4 \%)$ & $12(57.1 \%)$ & $15(71.4 \%)$ & $17(81.0 \%)$ & \\
\hline \multirow{2}{*}{$\begin{array}{l}\text { MS CoNS } \\
(n=22)\end{array}$} & Not susceptible & $1(4.5 \%)$ & $1(4.5 \%)$ & $0(0.0 \%)$ & $1(4.5 \%)$ & \multirow[t]{2}{*}{$p=0.733$} \\
\hline & Susceptible & $21(95.5 \%)$ & $21(95.5 \%)$ & $22(100 \%)$ & $21(95.5 \%)$ & \\
\hline
\end{tabular}

\begin{tabular}{|c|c|c|c|c|c|c|}
\hline Groups & Result & Cipro & Oflox & Gati & Moxi & Friedman test \\
\hline \multirow{2}{*}{$\begin{array}{l}\text { MR CoNS } \\
(n=21)\end{array}$} & Not susceptible & $15(71.4 \%)$ & $6(76.2 \%)$ & 13 (61.9\%) & $14(66.7 \%)$ & $p=0.232$ \\
\hline & Susceptible & $6(28.6 \%)$ & $5(23.8 \%)$ & $8(38.1 \%)$ & 7 (33.3\%) & \\
\hline \multirow{2}{*}{$\begin{array}{l}\text { MS CoNS } \\
(n=22)\end{array}$} & Not susceptible & $1(4.5 \%)$ & $2(9.1 \%)$ & $1(4.5 \%)$ & $1(4.5 \%)$ & $p=0.392$ \\
\hline & Susceptible & 21 (95.5\%) & $20(90.9 \%)$ & $21(95.5 \%)$ & 21 (95.5\%) & \\
\hline
\end{tabular}

\section{DISCUSSION}

As has been well demonstrated in the infectious disease literature, resistant strains are developing with increasing use of an antibiotic ${ }^{(5)}$. As a result, periodic susceptibility surveys are important to detect emerging resistance patterns, which may become clinically significant.

In the here described study, we examined the in vitro susceptibility of coagulase-negative staphylococci to fluoroquinolone antibiotics. The $\mathrm{MIC}^{90}$ values for the methicillinresistant group were higher then those for the methicillinsusceptible group. Both groups of staphylococci were more susceptible to gatifloxacin and moxifloxacin than they were to ciprofloxacin and ofloxacin.

Table 6. Comparison between $\mathrm{MIC}^{90}$ values in our studies and Kolwaski's 2003/USA ${ }^{(13)}$

\begin{tabular}{llcccc} 
& & \multicolumn{4}{c}{ MIC $^{90}$} \\
\cline { 3 - 6 } MR CoNS & Brazil & 3 & 2 & 32 & 32 \\
& Kolwaski 2003 & 3 & 3 & 64 & 64 \\
MS CoNS & Brazil & 0.75 & 1 & 2 & 6 \\
& Kolwaski 2003 & 0.125 & 0.19 & 0.38 & 0.75
\end{tabular}

Moxi= moxifloxacin; Gati= gatifloxacin; Cipro= ciprofloxacin; Oflox= ofloxacin; MR CoNS=Methicillin-resistant coagulase-negative Staphylococcus; MS CoNS=

Methicillin-susceptible coagulase-negative Staphylococcus
The differences observed for the diffusion susceptibilities compared with the E-test results for CoNS could be explained by the fact that CLSI/NCCLS considers the standards for all drugs with no deterrents regarding the species. Probably in the future new studies would differentiate the level of antibiotic susceptibility based not on the group of CoNS but based on the species.

In 2002, Mather and colleagues determined the median MICs for 93 bacterial endophthalmitis isolates using the E-test approach. The results of the study demonstrated that comparing the median MICs for the fourth-generation agents, moxifloxacin was more potent than gatifloxacin against fluoroquinolone susceptible CoNS; and equally potent against fluoroquinolone-resistant CoNS ${ }^{(17)}$.

Our results are supported by those of Stroman and associates, who similarly presented MIC data demonstrating the high potency of moxifloxacin ${ }^{(18)}$.

Some authors studying bacterial keratitis isolates, found that fluoroquinolone-susceptible and resistant CoNS were equally susceptible to the second and fourth generation. The MIC of moxifloxacin was equivalent to that of gatifloxacin for fluoroquinolone-resistant CoNS. In our study, the $\mathrm{MIC}^{90}$ was lower for gatifloxacin than that of moxifloxacin for MR CoNS, but equal for CoNS ${ }^{(13)}$ (Tables 6 and 7).

Other authors published that ocular $S$. epidermidis retrieved from conjunctivitis are clearly more susceptible to moxi-

\begin{tabular}{|c|c|c|c|c|c|c|}
\hline & \multicolumn{6}{|c|}{ MIC $^{90}$} \\
\hline & $\mathbf{n}$ & Potency & Cipro & Oflox & Gati & Moxi \\
\hline MRCoNS & 21 & gati $>$ moxi $>$ cipro $=$ oflox & 32 & 32 & 2 & 3 \\
\hline MSCoNS & 22 & moxi $>$ gati $>$ cipro $>$ oflox & 0.25 & 1.0 & 0.125 & 0.125 \\
\hline
\end{tabular}


floxacin than ciprofloxacin throughout three different parts of world (USA, Europe and India), based on the $\mathrm{MIC}^{90} \mathrm{~s}^{(19)}$.

Fluoroquinolone antibiotics are concentration-dependent killers in that the MIC must be reached for the antibiotic to be effective. These values are based on CLSI/NCCLS criteria related to the drug concentration that is safely achievable in plasma, and do not reflect the concentration achievable with topical application. Therefore, some isolates classified as intermediate or resistant might be sensitive if the ocular tissue levels are much greater than those of serum. The CLSI/NCCLS standards indicate also that systemic penetration for effective therapy is similar among the fluoroquinolones tested in our study. It would thus be reasonable to assume that similar, perhaps even higher levels can be reached in the ocular tissues. If we assume that antibiotic concentrations in ocular tissues following topical administration are at least equivalent to (if not higher than) systemic penetration, the key parameter to consider in comparing antibiotic effectiveness is the MIC value: the antibiotic with the lowest MIC for a bacterial group would be the most potent. Furthermore, the most potent antibiotic would have the least chance of causing resistance because the concentration in the ocular tissues would less likely be sublethal.

Primary use of the newer fluoroquinolones in preference to use of the older fluoroquinolones provides the potential for helping to forestall the development of resistance, but this approach must be coupled with the overall strategy of avoiding indiscriminate use of and ensuring proper dosing with these antimicrobials ${ }^{(3)}$.

\section{CONCLUSION}

Our in vitro study suggests that the fourth generation fluoroquinolones are more potent than are the second and third generation fluoroquinolones against coagulase-negative staphylococci, particularly those resistant to methicillin.

\section{RESUMO}

Objetivos: Avaliar a suscetibilidade a fluorquinolonas dos Staphylococcus coagulase-negativo (SCoN) identificados no Laboratório de Microbiologia Ocular da UNIFESP. Métodos: Foi determinada a concentração inibitória mínima de 21 cepas de SCoN meticilina-resistentes e 22 meticilina-sensíveis para ciprofloxacina, ofloxacina, gatifloxacina e moxifloxacina, utilizando o E-test estandartizado pelo CLSI/NCCLS. Resultados: Os $\mathrm{MIC}^{90}(\mu \mathrm{g} / \mathrm{ml})$ de $43 \mathrm{SCoN}$ isolados para fluorquinolonas de segunda geração foram maiores do que os de quarta geração, principalmente para o grupo dos meticilina-resistentes. Conclusão: Nossos resultados indicam que Staphylococcus coagulase-negativo meticilina-sensíveis são mais suscetíveis às quinolonas do que os Staphylococcus coagulase-negativo meticilina-resistentes, fluorquinolonas de quarta geração parecem ser mais potentes, cobrindo inclusive cepas de Staphy- lococcus coagulase-negativo resistentes à segunda geração de fluorquinolonas.

Descritores: Resistência microbiana a drogas; Infecções oculares bacterianas/microbiologia; Staphylococcus/isolamento \& purificação; Coagulase; Fluoroquinolonas; Resistência a meticilina

\section{REFERENCES}

1. Pinna A, Zanetti S, Sotgiu M, Sechi LA, Fadda G, Carta F. Identification and antibiotic susceptibility of coagulase negative staphylococci isolated in corneal/ external infections. Br J Ophthalmol. 1999;83(7):771-3. Comment in: Br J Ophthalmol. 2000;84(2):229.

2. Ta CN, Chang RT, Singh K, Egbert PR, Shriver EM, Blumenkranz MS, et al. Antibiotic resistance patterns of ocular bacterial flora: a prospective study of patients undergoing anterior segment surgery. Ophthalmology. 2003;110(10): 1946-51.

3. Wong TY, Chee SP. The epidemiology of acute endophthalmitis after cataract surgery in an Asian population. Ophthalmology. 2004;111(4):699-705. Comment in: Ophthalmology. 2005;112(5):944; author reply 944.

4. Fukuda M, Ohashi H, Fukuda M, Ohashi H, Matsumoto C, Mishima S, et al. Methicillin-resistant Staphylococcus aureus and methicillin-resistant coagulasenegative Staphylococcus ocular surface infection efficacy of chloramphenicol eye drops. Cornea. 2002;21(7 Suppl):S86-9.

5. Goldstein MH, Kowalski RP, Gordon YJ. Emerging fluoroquinolone resistance in bacterial keratitis: a 5-year review. Ophthalmology. 1999;106(7):1313-8.

6. Calderón-Jaimes E, Espinosa de los Monteros LE, Avila-Beltrán R. Epidemiology of drug resistance: the case of Staphylococcus aureus and coagulasenegative staphylococci infections. Salud Publica Mex. 2002;44(2):108-12.

7. Gayoso MFA, Oliveira ADD, D'Azevedo PA, et al. Antimicrobial susceptibilities of ocular isolated coagulase-negative staphylococcus (CoNS) in São Paulo, Brazil. Arq Bras Oftalmol. No prelo.

8. Leibowitz HM. Clinical evaluation of ciprofloxacin $0.3 \%$ ophthalmic solution for treatment of bacterial keratitis. Am J Ophthalmol. 1991;112(4 Suppl):34S-47S.

9. Leibowitz HM. Antibacterial effectiveness of ciprofloxacin $0.3 \%$ ophthalmic solution in the treatment of bacterial conjunctivitis. Am J Ophthalmol. 1991; 112(4 Suppl):29S-33S.

10. Alexandrakis G, Alfonso EC, Miller D. Shifting trends in bacterial keratitis in south Florida and emerging resistance to fluoroquinolones. Ophthalmology. 2000;107(8):1497-502.

11. Chalita MR, Hofling-Lima AL, Paranhos A Jr, Schor P, Belfort R Jr. Shifting trends in vitro antibiotic susceptibilities for common ocular isolates during a period of 15 years. Am J Ophthalmol. 2004;137(1):43-51.

12. Hooper DC. Fluoroquinolone resistance among Gram-positive cocci. Lancet Infect Dis. 2002;2(9):530-8.

13. Kowalski RP, Dhaliwal DK, Karenchak LM, Romanowski EG, Mah FS, Ritterband DC, et al. Gatifloxacin and moxifloxacin: an in vitro susceptibility comparison to levofloxacin, ciprofloxacin, and ofloxacin using bacterial keratitis isolates. Am J Ophthalmol. 2003;136(3):500-5.

14. Marangon FB, Miller D, Muallem MS, Romano AC, Alfonso EC. Ciprofloxacin and levofloxacin resistance among methicillin-sensitive Staphylococcus aureus isolates from keratitis and conjunctivitis. Am J Ophthalmol. 2004;137 (3):453-8.

15. Scheld WM. Maintaining fluoroquinolone class efficacy: review of influencing factors. Emerg Infect Dis. 2003;9(1):1-9. Comment in: Emerg Infect Dis. 2003;9(12):1651-4. Emerg Infect Dis. 2004;10(1):156-7.

16. Clinical and Laboratory Standard Institute. Performance Standards for Antimicrobial Susceptibility Testing. Fifteenth Informational Supplement. M100S15. This document provides updated for the M2-A8 and M7-A6 [text on the Internet]. Wayne, Pennsylvania: CLSI; 2005. [cited 2006 Dec 27]. Available from: http://enews.clsi.org/clsi/issues/2006-02-01/4.html

17. Mather R, Karenchak LM, Romanowski EG, Kowalski RP. Fourth generation fluoroquinolones: new weapons in the arsenal of ophthalmic antibiotics. Am J Ophthalmol. 2002;133(4):463-6.

18. Stroman DW, Clark L, Macke L, Mendoza B, Schlech B, Brien TO. Moxifloxacin activity against quinolone resistant Staphylococcal ocular isolates. Invest Ophthalmol Vis Sci. 2001;42(suppl 4):1377.

19. Stroman DW, Dajcs JJ, Cupp GA, Schlech BA. In vitro and in vivo potency of moxifloxacin and moxifloxacin ophthalmic solution $0.5 \%$, a new topical fluoroquinolone. Surv Ophthalmol. 2005;50(6 Suppl):S16-31. 